\title{
Correction to: Luxury Ethical Consumers: Who Are They?
}

\author{
Joëlle Vanhamme ${ }^{1} \cdot$ Adam Lindgreen $^{2,3}$ (1) $\cdot$ Gülen Sarial-Abi ${ }^{4}$
}

Published online: 30 November 2021

(c) Springer Nature B.V. 2021

\section{Correction to: Journal of Business Ethics https://doi.org/10.1007/s10551-021-04981-3}

The initial online publication contained a typesetting mistake in the affiliation of author Joëlle Vanhamme. The affiliation was incorrectly given as 'Business School' but should have been 'EDHEC Business School'.
The original article has been corrected.

Publisher's Note Springer Nature remains neutral with regard to jurisdictional claims in published maps and institutional affiliations.

The original article can be found online at https://doi.org/10.1007/ s10551-021-04981-3.

Adam Lindgreen adli.marktg@cbs.dk

Joëlle Vanhamme

joelle.vanhamme@edhec.edu

Gülen Sarial-Abi gsa.marktg@cbs.dk

1 EDHEC Business School, 24 avenue Gustave Delory, CS 50411, 59057 Roubaix Cedex 1, France

2 Department of Marketing, Copenhagen Business School, Solbjerg Plads 3, 2000 Frederiksberg C, Denmark

3 University of Pretoria's Gordon Institute of Business Science, 26 Melville Road, Illovo, Johannesburg, South Africa

4 Department of Marketing, Copenhagen Business School, Solbjerg Plads 3, 2000 Frederiksberg, Denmark 